\title{
Analisis Rasio Keuangan Pada PT. Bluebird Tbk Setelah Adanya Sarana Transportasi Berbasis Online
}

\author{
Marchel R. A. Goni \\ Dolina L. Tampi \\ Wilfred S. Manopo \\ Jurusan Ilmu Admnistrasi , Program Studi Administrasi Bisnis \\ Fakultas Ilmu Sosial dan Politik, Universitas Sam Ratulangi \\ marchel.goni@gmail.com
}

\begin{abstract}
The purpose of this study was to analyze the Financial Ratio at PT Bluebird Tbk after the existence of online-based transportation facilities. The company's problem arose since the entry of online transportation facilities where there was a significant decrease in income. Ratio analysis in the opinion of Munawir An analytical method to determine the relationship of certain items in the balance sheet or income statement individually or in a combination of the two reports. The research method used is liquidity ratio, solvability ratio and profitability ratio. The results show that the relationship between liquidity and solability can be said to be "liquid and solvable", meaning that the condition of the company is declared healthy and in good condition because the company is able to pay off its obligations that are due on time. Furthermore, the relationship between solvency and profitability can be said as "solvabel and inprofit", meaning that the condition of total corporate debt tends to decrease, not accompanied by a decrease in profit from year to year. Declining profit growth does not affect the rate of return on short-term debt from the company. This means that even though profits are reduced, the company can still return the current debt fairly well. Thus, after the entry of other online-based transportation facilities there is a downward trend in indicators of profitability, while in the other two indicators tend to be in a good position. This is because the company has not been able to manage financial performance in terms of profitability efficiently.
\end{abstract}

Keyword : Financial statements, Analysis Ratio

\section{Pendahuluan}

Transportasi adalah sarana yang tujuannya untuk menghubungkan antara dua orang atau lebih yang terbentang antar jarak yang cukup jauh atau pun dekat. Salah satu perusahaan transportasi di Indonesia adalah Bluebird Group.

Masalah mulai muncul ketika transportasi ini mulai memiliki saingan yang menjual jasa pada transportasi yang ada. Pada tahun 2015, pendapatan senilai $\mathrm{Rp} 5,4$ triliun menigkat $10,1 \%$ dari pendapatan 2014 (secara nasional), dan terdapat kesenjangan antara ekspektasi dan kenyataan ditahun berikutnya.

Pada laporan keuangan 2016 terjadi penurunan pendapatan yang cukup signifikan. Perbandingan jumlah pendapatan pada tahun 2016 menurun 12,3\% menjadi Rp 4,7 triliun. 
Pada tahun 2017 perusahaan tetap mengalami penurunan penjualan sebanyak 12,3\% menjadi 4,2 triliun. Diperkirakan semenjak masuknya perusahaan transportasi berbasis online terjadi penurunan keuntungan yang signfikan terhadap perusahaan. untuk itu dilakukan penelitian dengan alat analisis rasio.

\section{Bisnis Transportasi}

Bisnis transportasi adalah suatu usaha seseorang atau kelompok untuk memenuhi kebutuhan atau keinginan seseorang untuk berpindah tempat baik seseorang atau suatu barang yang memiliki manfaat tertentu dengan menggunakan sarana pendukung tertentu. Bisnis transportasi terdiri dari transportasi darat, laut dan udara.

\section{Laporan Keuangan}

Menurut Hanafi (2003), laporan keuangan merupakan informasi yang dapat dipakai untuk pengambilan keputusan, mulai dari investor atau calon investor sampai dengan manajemen perusahaan itu sendiri. Laporan keuangan akan memberikan informasi mengenai profitabilitas, risiko, proses aliran kas, yang kesemuanya akan mempengaruhi harapan pihak-pihak yang berkepentingan.

\section{Jenis - Jenis Laporan Keuangan}

Menurut Warsono (2001) ada 2 macam bentuk laporan keuangan utama yang dihasilkan oleh suatu perusahaan yaitu Neraca dan Laporan laba rugi.
1. Neraca

Neraca adalah laporan keuangan yang menggambarkan posisi keuangan suatu organisasi pada suatu periode tertentu. Neraca perusahaan ini disusun berdasarkan persamaan dasar akuntansi, yaitu bahwa kekayaan atau aktiva (asets) sama dengan kewajiban (liabilities) ditambah modal saham (stock equities).

2. Laporan Laba - Rugi

Laporan laba-rugi adalah laporan keuangan yang mengambarkan hasil-hasil usaha yang dicapai selama periode tertentu. Laba rugi bersih adalah selisih antara pendapatan total dengan biaya atau pengeluaran total.

\section{Analisis Laporan Keuangan}

Menurut Hanafi (2003), suatu analisis laporan keuangan perusahaan pada dasarnya karena ingin mengetahui tingkat profitabilitas (keuntungan) dan tingkat risiko atau tingkat kesehatan suatu perusahaan.

\section{Analisis Rasio}

Menurut pendapat Munawir (2007), analisis rasio ialah suatu metode analisis untuk mengetahui hubungan dari pos-pos tertentu dalam neraca atau laporan labarugi secara individual atau kombinasi dari kedua laporan tersebut.

\section{Jenis - Jenis Analisis Rasio}

1. Rasio Likuiditas

Menurut Sartono (2011), rasio likuiditas adalah rasio yang menunjukkan kemampuan perusahaan untuk memenuhi 
kewajiban finansial yang berjangka pendek tepat pada waktunya.

2. Rasio Aktivitas

Menurut Sartono (2011), rasio aktivitas adalah rasio yang menunjukkan sejauh mana efisiensi perusahaan dalam menggunakan aset untuk memperoleh penjualan.

3. Rasio Solvablitas

Menurut Sartono (2011), rasio solvabilitas adalah rasio yang menunjukkan kapasitas perusahaan untuk memenuhi kewajiban jangka pendek maupun jangka panjang.

4. Rasio Profitabilitas

Menurut Sartono (2011), rasio profitabilitas adalah rasio yang dapat mengukur kemampuan perusahaan memperoleh laba, baik dalam hubungan dengan penjualan, asset maupun modal sendiri.

\section{Metode Penelitian}

Penelitian ini dikategorikan dalam suatu bentuk penelitian deskriptif pendekatan kuantitatif. Penelitian deskriptif adalah penelitian yang dilakukan untuk mengetahui variabel mandiri, baik atau variabel atau lebih (independen) tanpa membuat perbandingan, atau menghubungkan dengan variabel lain (Sugiyono 2014).

Jenis data yang digunakan dalam penelitian yang saya jalankan ini yakni adalah data sekunder yaitu data yang diterbitkan atau digunakan kemudian diolah dan dianalisis dengan menggunakan alat - alat analisis yang ada.
Data yang diperoleh dari objek penelitian berupa gambaran umum PT. Bluebird Tbk, struktur organisasi serta laporan Keuangan tahun 2015, 2016 dan 2017.

Proses pengumpulan data yang diperlukan dalam pembahasan ini adalah dokumentasi dan studi kepustakaan serta kajian literatur.

Data yang telah terkumpul akan dianalisis menggunakan alat analisis berupa rasio keuangan yang meliputi:

1) Rasio Likuiditas adalah rasio yang menggambarkan kemampuan perusahaan dalam memenuhi kewajiban jangka pendek yang segera jatuh tempo;

2) Rasio Solvabilitas adalah rasio yang menunjukan kemampuan perusahaan dalam memenuhi segala kewajibannya baik jangka pendek maupun jangka panjang;

3) Rasio Profitabilitas, adalah rasio yang digunakan untuk mengukur kemampuan suatu perusahaan dalam mendapatkan laba.

\section{Hasil Penelitian}

Tabel 1. Curent Ratio Laporan Keuangan PT. Bluebird Tbk.

\begin{tabular}{cc}
\hline Tahun & Curent Ratio \\
\hline 2015 & $59 \%$ \\
2016 & $108 \%$ \\
2017 & $177 \%$ \\
\hline Rata - Rata & $\mathbf{1 1 5 \%}$ \\
\hline Sumber : Data Hasil Olahan
\end{tabular}


Dari tabel diatas dapat dilihat bahwa terjadi kenaikan jumlah curent ratio dari tahun ketahun dan jumlah rata - ratanya sebesar $115 \%$.

Tabel 2. Deskripsi Data Quick Ratio Terhadap Laporan Keuangan PT. Bluebird Tbk.

\begin{tabular}{cc}
\hline Tahun & Quick Ratio \\
\hline 2015 & $57 \%$ \\
2016 & $107 \%$ \\
2017 & $174 \%$ \\
\hline Rata - Rata & $\mathbf{1 1 3 \%}$ \\
\hline Sumber : Data Hasil Olahan
\end{tabular}

Dari tabel diatas dapat dilihat bahwa terjadi kenaikan jumlah quick ratio dari tahun ketahun dan jumlah rata - ratanya sebesar $113 \%$.

Tabel 3. Deskripsi Data Cash Ratio Terhadap Laporan Keuangan PT. Bluebird Tbk.

\begin{tabular}{cc}
\hline Tahun & Cash Ratio \\
\hline 2015 & $28 \%$ \\
2016 & $73 \%$ \\
2017 & $109 \%$ \\
\hline Rata - Rata & $\mathbf{7 0 \%}$ \\
\hline Sumber : Data Hasil Olahan
\end{tabular}

Dari tabel diatas dapat dilihat bahwa terjadi kenaikan jumlah cash ratio dari tahun ketahun dan jumlah rata - ratanya sebesar $70 \%$.
Tabel 4. Deskripsi Data Total Debt To Total Assets Ratio Terhadap Laporan Keuangan PT. Bluebird Tbk.

\begin{tabular}{lc}
\hline Tahun & $\begin{array}{c}\text { Total Debt To Total } \\
\text { Assets Ratio }\end{array}$ \\
\hline 2015 & $39 \%$ \\
2016 & $36 \%$ \\
2017 & $24 \%$ \\
\hline Rata - Rata & $\mathbf{3 3 \%}$ \\
\hline Sumber : Data Hasil Olahan \\
\\
Dari tabel diatas dapat dilihat bahwa \\
terjadi penurunan jumlah total debt to total \\
assets ratio dari tahun ketahun dan jumlah \\
rata - ratanya sebesar 33\%.
\end{tabular}

Tabel 5. Deskripsi Data Total Debt To Equity Ratio Terhadap Laporan Keuangan PT. Bluebird Tbk.

\begin{tabular}{cc}
\hline Tahun & $\begin{array}{c}\text { Total Debt } \\
\text { To Equity } \\
\text { Ratio }\end{array}$ \\
\hline 2015 & $65 \%$ \\
2016 & $57 \%$ \\
2017 & $32 \%$ \\
\hline Rata - Rata & $\mathbf{5 1 \%}$ \\
\hline Sumber : Data Hasil Olahan
\end{tabular}

Dari tabel diatas dapat dilihat bahwa terjadi penurunan jumlah total debt to equity ratio dari tahun ketahun dan jumlah rata - ratanya sebesar $51 \%$

Tabel 6. Deskripsi Data Gross Profit Margin (GPM) Terhadap Laporan Keuangan PT. Bluebird Tbk. 


\begin{tabular}{cc}
\hline Tahun & GPM \\
\hline 2015 & $20 \%$ \\
2016 & $14 \%$ \\
2017 & $13 \%$ \\
\hline Rata - Rata & $\mathbf{1 6 \%}$ \\
\hline Sumber : Data Hasi Olahan
\end{tabular}

Sumber : Data Hasil Olahan

Dari tabel diatas dapat dilihat bahwa terjadi Penurunan jumlah GPM dari tahun ketahun dan jumlah rata - ratanya sebesar $16 \%$.

Tabel 7. Deskripsi Data Net Profit Margin (NPM) Terhadap Laporan Keuangan PT. Bluebird Tbk.

\begin{tabular}{cc}
\hline Tahun & NPM \\
\hline 2015 & $15 \%$ \\
2016 & $11 \%$ \\
2017 & $10 \%$ \\
\hline Rata - Rata & $\mathbf{1 2 \%}$ \\
\hline \multicolumn{2}{l}{ Sumber : Data Hasil Olahan }
\end{tabular}

Dari tabel diatas dapat dilihat bahwa terjadi Penurunan jumlah NPM dari tahun ketahun dan jumlah rata - ratanya sebesar $12 \%$

Tabel 8. Deskripsi Data Return On Equity (ROE) Terhadap Laporan Keuangan PT. Bluebird Tbk.

\begin{tabular}{cr}
\hline Tahun & \multicolumn{1}{c}{ ROE } \\
\hline 2015 & $19 \%$ \\
2016 & $11 \%$ \\
2017 & $9 \%$ \\
\hline Rata - Rata & $\mathbf{1 3 \%}$ \\
\hline Sumber : Data Hasil Olahan
\end{tabular}

Dari tabel diatas dapat dilihat bahwa terjadi Penurunan jumlah ROE dari tahun ketahun dan jumlah rata - ratanya sebesar $13 \%$.

\section{Pembahasan}

Dari hasil perhitungan disimpulkan dalam hasil analisis sebagai berikut :

1. Rasio Likuiditas

- Curent Ratio

Dari penjelasan di atas dapat disimpulkan bahwa perusahaan meski belum mencapai standar industri tetap dalam tahap kenaikan dan cenderung membaik dari tahun ke tahun.

- Quick Ratio

Dari penjelasan tersebut dapat disimpulkan bahwa kinerja perusahaan dalam pengelolahan keuangan jika dilihat dari quick ratio cenderung membaik dikarenakan kenaikan dari tahun ketahun.

- Cash Ratio

Dapat disimpulkan bahwa kinerja keuangan PT. Bluebird Tbk cenderung baik jika mengikuti hasil analisis rasio kas dari perusahaan.

2. Rasio Solvabilitas

- $\quad$ Total Debt To Total Assets Ratio

Dapat disimpulkan bahwa kondisi perusahaan mengikuti standar industri cenderung baik karena pembiayaan hutang terhadap aset cenderung menurun dari tahun ke tahun.

- Total Debt To Equity Ratio

Dan dapat di simpulkan bahwa kinerja keuangan perusahaan melalui pendekatan 
debt to equity ratio "sangat baik" dan perusahaan tetap dapat menjalankan operasionalnya dengan baik.

\section{Rasio Profitabilitas}

\section{- Gross Profit Margin (GPM)}

Dapat disimpulkan bahwa kinerja keuangan melalui pendekatan GPM berada pada posisi "kurang baik" karena jumlah GPM dari tahun ketahun masih berada dibawah standar industri yang ditetapkan.

- $\quad$ Net Profit Margin (NPM)

Dari data tersebut dapat disimpulkan bahwa perusahaan berada pada posisi 'kurang baik' dalam tingkat laba bersih yang didapat dari penjualan karena jumlah NPM masih dibawah standar industri yang ditetapkan.

- Return On Equity (ROE)

Dapat disimpulkan bahwa posisi keuangan perusahaan ada pada kondisi 'kurang baik' dikarenakan jumlah ROE masih dibawah standar industri yang ditetapkan.

\section{Kesimpulan}

Berdasarkan hasil analisis dari data melalui metode analisis rasio keuangan setelah masuknya sarana transportasi berbasis online PT. Bluebird Tbk, maka dapat diambil beberapa kesimpulan sebagai berikut :

Rasio likuiditas adalah untuk mengukur kemampuan perusahaan dalam memenuhi kewajiban jangka pendeknya melalui indikator curent ratio, quick ratio, dan cash rasio berada pada posisi "cukup baik" di karenakan mendekati periode akhir perusahaan dapat memenuh standar industri yang ditetapkan.

Rasio Solvabilitas adalah untuk menunjukkan kapasitas perusahaan untuk memenuhi kewajiban jangka pendek maupun jangka panjang melalui indikator total debt to total assets ratio dan debt to equity ratio memperlihatkan posisi perusahaan dalam keadaan "baik", dimana berusahaan dapat memenuhi standar industri yang ditetapkan.

Rasio Profitabilitas adalah rasio yang dapat mengukur kemampuan perusahaan memperoleh laba, baik dalam hubungan dengan penjualan, asset maupun modal sendiri melalui indikator gross profit margin, net profit margin dan return on equity dapat disimpulkan bahwa tingkat profitabilitas perusahaan berada pada posisi "kurang baik" dimana laba dan penjualan yang cenderung menurun dalam selang waktu tiga tahun terakhir. Ketiga indikator berada dibawah standar industri sehingga perusahaan di nyatakan dalam posisi "kurang baik".

Dari pengamatan melalui analisis indikator rasio keuangan dapat disimpulkan bahwa setelah masuknya sarana transportasi berbasis online lain nya terdapat kecenderungan penurunan dalam indikator profitabilitas, sedangkan dalam dua indikator lainnya cenderung berada pada posisi baik. Jadi dapat disimpulkan 
bahwa masuknya sarana transportasi online hanya berdampak pada tingkat profitabilitas perusahaan.

\section{Saran}

Mengacu pada hasil temuan dalam penelitian ini, maka dipandang perlu untuk memberikan saran, sebagai berikut :

Untuk meningkatkan kinerja indikator likuiditas maka pihak perusahaan harus berupaya untuk meningkatkan pertumbuhan aktiva lancar melalui peningkatan volume kas, piutang, investasi jangka pendek. Dipihak lain, manajemen keuangan perusahaan perlu mengurangi volume hutang kancar dengan pembayaran tepat waktu.

Untuk meningkatkan kinerja indikator solvabilitas diperlukan manajemen pengambilan keputusan yang tepat untuk mengurangi beban hutang jangka pendek dan jangka panjang sambil meningkatkan total aset yang perusahaan.

Untuk meningkatkan kinerja indikator profitabilitas maka pihak perusahaan harus berupaya dengan melakukan pengontrolan terhadap kegiatan operasional serta memikirkan strategi bisnis yang inovatif agar supaya tidak dapat tertinggal atau tidak dapat bersaing dengan perusahaan yang memiliki bidang bisnis yang serupa.

Untuk memaksimalkan ketiga indikator diatas perusahaan perlu melakukan pengambilan keputusan keuangan yang tepat sasaran, dimana mengikuti perkembangan zaman yang semakin dinamis dimana perusahaan dituntut untuk terus berinovasi terutama dalam melakukan keputusan investasi yang kiranya dapat merubah arah kinerja keuangan menjadi lebih baik.

\section{Daftar Pustaka}

Barus, M. A dan N. Sudjana. 2017. Penggunaan Rasio Keuangan Untuk Mengukur Kinerja Keuangan Perusahaan. Jurnal Administrasi Bisnis. 44 (1). 154 163.

Fahmi, I. 2014. Analisis Kinerja Keuangan. Bandung. Alfabeta.

Harmono. 2009. Manajemen Keuangan. Cetakan Pertama. Yogyakarta. Bumi Aksara.

Harmono. 2018. Manajemen Keuangan Berbasis Balanced Scorecard. Jakarta. Bumi Aksara.

Maith, H. A. 2013. Analisis Laporan Keuangan Dalam Mengukur Kinerja Keuangan Pada PT. Hanjaya Mandala Sampoerna Tbk. Jurnal EMBA.1 (3). 619 - 628.

Prihadi, Toto. 2008. Deteksi Cepat Kondisi Keuangan. Tujuh Analisis Rasio Keuangan. Cetakan Pertama. PPM. Jakarta.

Sugiono, A dan E. Untung. 2016. Panduan Praktis Dasar Analisa Laporan Keuangan. Jakarta. Grasindo.

Sugiyono. 2017. Metode Penelitian Bisnis. Bandung. Alfabeta. 
Jurnal Administrasi Bisnis

Vol. 8. No. 1, 2019

(p-ISSN 2338-9605; e-2655-206X)

Suripto. 2015. Manajemen Keuangan

Strategi Penciptaan Nilai

Perusahaan Melalui Pendekatan

Economic Value Added.

Yogyakarta. Graha Ilmu. 